\title{
Fenomenologia ja tiedon luominen työyhteisöissä
}

\author{
Anna Suorsa \\ Oulun yliopisto \\ anna.suorsa@oulu.fi
}

FM Anna Suorsan väitöskirja "Vuorovaikutus tiedon luomisessa. Fenomenologinen tutkimus tietojohtamisen alalla" (Interaction for knowledge creation. A phenomenological study in Knowledge Management) tarkastettiin 31.3.2017 Oulun yliopiston humanistisessa tiedekunnassa. Vastaväittäjänä toimi professori John M. Budd (University of Missouri, USA) ja kustoksena professori Maija-Leena Huotari (Oulun yliopisto). Väitöskirja on julkaistu sarjassa Acta Universitatis Ouluensis. B, Humaniora ja se on luettavissa myös Oulun yliopiston Jultikajulkaisuarkistossa osoitteessa http://urn.fi/urn:isbn:9789566215235.

Asiasanat: vuorovaikutus; fenomenologia; tietojohtaminen

Tänään tarkastettavan väitöskirjani taustalla on työelämän nopea muuttuminen viime vuosikymmeninä. Tieto- ja viestintäteknologian kehittyessä ja globalisaation viedessä yhä useammat perinteiset, teolliset työpaikat halvempien kustannusten toivossa pois Suomesta, kuten länsimaista yleensäkin, on yhä suurempi osa tänne jäävästä ja syntyvästä työstä kiinnittynyt informaatioon ja tietoon. Perinteisen tehdastyön sijaan ihmiset työskentelevät aloilla, joiden toiminta liittyy informaation ja tiedon käsittelyyn ja jalostamiseen (Drucker, 1982, 1993). Tällaisten tietoperustaisten organisaatioiden toiminta edellyttääkin kehittyneitä tiedon jakamisen ja luomisen käytäntöjä sekä niiden johtamista ja hallintaa (Choo, 1998). Myös työn tekemisen tavat muuttuvat ja työtä tehdään yhä enemmän erilaisissa verkostoissa, tiimeissä ja työryhmissä, oli kyse sitten minkälaisesta työstä tahansa. Näistä tarpeista on viime 
vuosikymmeninä kehittynyt ajatus tietojohtamisesta yhtenä organisaatioiden johtamisen lajina. Tietojohtaminen organisaatioissa tähtää työntekijöiden asiantuntemuksen ja oppimisen tukemiseen sekä sellaisen ympäristön synnyttämiseen, jossa uuden tiedon luominen on mahdollista.

Tämän hetken Suomessa monet tahot vetoavat innovatiivisuuteen ja juuri uuden tiedon luomiseen - niiden nähdään olevan organisaatioiden elinehtoja kilpailun kiristyessä ja toimintaympäristön muuttuessa. Viimeaikaisten tutkimusten mukaan uutta tietoa syntyy erityisesti ihmisten välisessä vuorovaikutuksessa, joka on sopivan avointa ja luottamuksellista. Näin siksi, että uusien ajatusten ja ideoiden, kuten myös tuotteiden ja palvelujen kehittäminen vaatii myös kykyä kyseenalaistaa totuttuja toimintatapoja ja ajattelumalleja, omien ja muiden tekemisten kriittistäkin tarkastelua. (Morner \& Krogh, 2009; Tsoukas, 2009.) Vaikka nämä lähtökohdat on tutkimuksissa todettu ja ainakin puheen tasolla usein organisaatioissakin tiedostettu, työn tekemistä kuitenkin leimaa usein kiire ja rauhallisen keskustelun vaatiman ajan puuttuminen työyhteisön arjesta. Siksi on tärkeää tutkia, miten organisaation toiminnan kannalta onnistuneita vuorovaikutustilanteita voidaan tukea ja toisaalta kehittää sellaisia olosuhteita, jotka mahdollistavat ihmisten kohtaamisen.

Tutkimukseni lähtökohtana onkin ollut ymmärtää, minkälainen käsitys ihmisestä on sekä innovaatiopuheen että tietojohtamisen alalla tehdyn tiedon luomisen ja vuorovaikutuksen tutkimuksen taustalla. Väitöskirjassani esitän, että se, miten ihminen ymmärretään, määrittelee olennaisella tavalla sitä, miten tiedon luomista, vuorovaikutusta ja yhdessä olemista määritellään. Edelleen se, miten työelämästä ja vuorovaikutuksesta tutkimuksissa puhutaan, vaikuttaa myös siihen, miten työelämän vaatimuksia julkisessa puheessa käsitellään. Siksi olen halunnut tutkimuksessani avata ihmisenä olemisen ajatusta ja tarkastella ihmisenä olemista ja vuorovaikutusta erityisesti työelämässä. Tavoitteenani on ollut myös kirjoittaa auki joskus ehkä hankalaltakin vaikuttavia, fenomenologiseen lähestymistapaan perustuvia peruskäsitteitä. Näkemykseni on, että vaikkakin ainakin ennakkoon ajateltuna tutkimuksessani käyttämiä filosofi Martin Heideggerin (1985) ja Hans-Georg Gadamerin $(1999,2004)$ käsityksiä olemisesta, ajallisuudesta ja keskustelusta saatetaan pitää vaikeina, vielä vaikeampaa on ymmärtää tutkimusta, joka ei ole lausunut ääneen lähtökohtiaan ja ennakkokäsityksiään.

Tutkimukseni koostuu viidestä artikkelista ja niitä pohjustavasta kokoomaosasta. Yhdessä nämä osatutkimukset muodostavat viisivaiheisen kokonaisuuden. Ensimmäisessä vaiheessa tutkin, miten ihmistä ja vuorovaikutusta on tämän hetkisessä tiedon luomisen tutkimuksessa kuvattu ja esitän, että jättäessään määrittelemättä sen, minkälainen ihmiskäsitys tutkimusten taustalla on, monet tiedon luomisen tutkimukset - tahallaan tai tahattomasti - vahvistavat usein varsin psykologisoitunutta käsitystä ihmisestä tietokoneena, joka mielessään säilöö ja käsittelee 
sinne syötettyä dataa. Tutkimukseni toisessa vaiheessa esitän, miten fenomenologisen ihmiskäsityksen avulla tiedon luominen ja vuorovaikutus voitaisiin ymmärtää entistä kokonaisvaltaisemmin. Esitän myös Gadamerin hermeneuttiseen fenomenologiaan pohjautuvan ajatuksen leikistä erityisenä yhdessä olemisen tilana, jonka ymmärtäminen voisi auttaa käsittämään tiedon luomisen tapahtumaa toisin. Kolmannessa vaiheessa etenen tarkastelemaan, miten fenomenologinen käsitys tiedon luomisen tapahtumasta ja ihmisestä tiedon luojana vaikuttaa siihen, millä tavalla tuota ilmiötä voi tutkia ja esitän sekä vuorovaikutuksen tapahtumaan että sen kokemuksellisuuteen kiinnittyvän menetelmän ilmiön tutkimiseksi empiirisesti. Tutkimukseni neljännessä vaiheessa koettelen kehittämääni lähestymistapaa ja menetelmiä tosielämässä eli tutkin tiedon luomista yhdessä, moniammatillisessa yhteisössä. Tutkimukseni lopuksi tarkastelen kehittelemääni viitekehystä tuon empiirisen testauksen valossa.

Tutkimukseni etsii vaihtoehtoa lähestymistavalle, jota voidaan laajasti ottaen kutsua kognitiiviseksi. Termin määritteleminen vaihtelee, mutta tutkimuksessani kognitiivinen viittaa ajattelutapaan, joka korostaa yksilön sisäistä tiedon käsittelyn prosessia. Informaatiotutkimuksessa on viime vuosikymmeniin saakka ollut esillä pitkälti tällainen lähestymistapa, ja se soveltuukin joihinkin tutkimusongelmiin, kuten yksilön tiedonhakukäyttäytymisen tutkimukseen (Belkin, 1990; Budd, 1995; Ingwersen, 1982). Kuitenkin ihmisten välisten prosessien kuvauksen kannalta siihen kiinnittyminen on ongelmallista, mikä onkin pitkälti merkinnyt sitä, että organisaation ja johtamisen tutkimus on ohittanut merkittäviä kysymyksiä, kuten taidon, kokemuksen ja havaitsemisen tiedon luomisen elementteinä. Vähitellen on kuitenkin ymmärretty, että organisaatioiden kannalta olennainen tieto on paremmin käsitteellistettävissä historiasta riippuvaiseksi, kontekstisidonnaiseksi ja työprosesseissa syntyväksi. Tiedon luomisen tutkimuksessa onkin yhä enemmän korostettu sitä, miten organisaatiossa kehitetään niitä ihmisten välisiä prosesseja, joissa tieto liikkuu. (Nonaka, Krogh, \& Voelpel, 2006.) Kognitiivisen näkökulman taustalla oleva ihmiskäsitys on kuitenkin jäänyt kriittisen tarkastelun ulkopuolelle.

Tutkimukseni esittelee hermeneuttisen fenomenologian käsityksen ihmisestä, olemisesta ja vuorovaikutuksesta, joten on paikallaan avata hieman tuota filosofista traditiota. Länsimaisessa filosofiassa on kautta aikojen pohdittu tietoisuuden suhdetta ympäröivään maailmaan mieltäen nämä toisistaan perustavalla tasolla erillisiksi, ja siksi on päädytty asettamaan kysymyksiä kaiken olemassaolon perusteista: miten tieto maailmasta ja toisista ihmisistä on lainkaan saavutettavissa, onko maailma todella olemassa, mitä todisteita ihmisellä voi olla toisen ihmisen olemassaolosta ja edelleen olemassaolosta samankaltaisena ajattelevana ihmisenä? Tämän kaltaisten ongelmien syntyminen johtuu juuri siitä, että ihmiskuva ja maailmakäsitys perustuvat oletukselle tietoisuudesta ja ruumiista, subjektista ja objekteista erillisinä kappaleina maailmassa. Tällaiset ennakko-oletukset ovat Edmund Husserlis- 
ta lähtöisin olevan fenomenologisen tutkimusperinteen kritiikin kohteena. Husserl esittää ankaran tieteen vaatimuksessaan, että tieteellisen tiedon on otettava huomioon lähtökohtansa ja kyseenalaistettava luonnolliselta vaikuttava asenteensa, joka tosiasiassa perustuu itsestäänselvyyksinä otettuihin rakenteisiin ja oletuksiin. Tietoisuuden ja tarkkarajaisten objektiivisten subjektien olemassaoloa ei voida todistaa, joten ankaran filosofian, kuten tieteen ylipäänsä, on lähdettävä liikkeelle siitä, mikä on todettavissa, eli kulloinkin havaitusta. (Heinämaa, 1996.) Havainnosta lähtemällä maailma ja ihminen siinä on kuvattava toisin. Samalla näyttäytyy saavutettavissa olevan tiedon tosiasiallinen epämääräisyys: kaikki tieto perustuu itse asiassa havaittuun ja on siten kiinni havaitsijansa näkökulmasta. Fenomenologisen filosofian lähtökohtana onkin maailmassa olemisen ymmärtämisestä juontuva aikaan, paikkaan ja kokemukseen kiinnittyvä kuvaustapa. Siinä kuvaustavassa ihminen on aina ensisijaisesti maailmassa oleva, eikä erotettavissa yksilönä, objektina tai subjektina, eikä myöskään eroteltavissa mieleen ja ruumiiseen.

Mitä tällaisesta ihmisestä sitten voi sanoa? Millainen on se ihminen, joka käyttämäni fenomenologisen lähestymistavan avulla on hahmotettavissa? Ei niin selkeärajainen, vaan kuvattavissa koko olemisessaan, arkielämässään, omista lähtökohdistaan alati muuttuvana maailman ja ajan kulumisen mukana. Olennaista on se, miten käyttämäni fenomenologia kuvaa ihmisen olemisentapoja tavalla, joka auttaa ymmärtämään paitsi uuden tiedon luomisen haasteellisuutta, myös ihmisten kohtaamisessa piileviä radikaalejakin mahdollisuuksia muutokseen, uuden luomiseen ja oppimiseen. Ihmisellä on käyttämäni fenomenologisen käsityksen mukaan aina jonkinlainen olemisentapa ja ymmärrys olemisestaan. Ihminen voi suhtautua tähän olemiseensa eri tavoin, mutta joka tapauksessa hän aina suhtautuu jotenkin. Koska ihminen kykenee ymmärtämään oman olemisensa, hänellä on myös kyky muuttaa sitä, toimia toisin, tarttuen tilanteessa oleviin mahdollisuuksiin. Ihminen on kehittynyt siksi, mitä hän kulloinkin on juuri koska on elänyt omanlaisensa elämän, mikä tietenkin vaikuttaa hänen kykyynsä toimia toisin. Hän näyttäytyy kuitenkin aina mahdollisuuksissaan olevana, niihin tarttuvana tai tarttumisesta kieltäytyvänä. Kohdatessaan toisen ihminen siis toimii aina mahdollisuuksistaan käsin, mutta nämä mahdollisuudet eivät ole ennalta määrätyt, vaan kohtaamisen luonne määrittyy tapahtumassa ollessa, ihmisen tarttuessa mahdollisuuksiin tai laiminlyödessä ne. Tuleva avautuu siis avoimena ja ennalta määrittelemättömänä. Toisaalta on myös mahdollista, että ihminen ei tartukaan tilanteessa aukeaviin mahdollisuuksiin ja mitään uutta ei synny. Erityistä tässä ajattelussa on, että tämäkin nähdään valintana, joka osaltaan vahvistaa maailman kehittymistä, siihen suuntaan, johon ihmiset olemisessaan sitä kulloinkin vievät. (Heidegger, 1985.) Tämä on ollut lähtökohtana tietoa luovan vuorovaikutuksen tutkimiselle väitöskirjassani.

Miten sitten vuorovaikutusta voidaan ymmärtää tästä fenomenologisesta lähtökohdasta käsin? Väitöskirjassani tarkastelin vuorovaikutuksen tapahtumaa Hans- 
Georg Gadamerin hermeneuttisen fenomenologian käsittein. Gadamerin mukaan kohtaamisen tapahtuma, jota voidaan kutsua vuorovaikutukseksi, on jotakin varsin radikaalia, joka sisältää mahdollisuuden suuriinkin muutoksiin. Ihmisellä on mahdollisuus jokaisessa kohtaamissa asettua avoimeen vuoropuheluun kumppaninsa kanssa, tavoitteena omat ennakkoluulonsa kyseenalaistaen ymmärtää paremmin itseään ja ympäristöään. Kyse on ihmisen perustavasta tavasta kohdata maailma, havaita ja kehittyä havaintojensa ymmärtämisen myötä. Gadamerin hermeneutiikassa erityistä on kriittisen tarkastelun tiedostaminen, omien ennakkonäkemysten oikeutuksen jatkuva tutkiminen ja tuon tutkimisen kohde. Gadamerilla keskustelun tarkoituksena ei nimittäin ole toisen pään sisälle meneminen, hänen sanomansa takana olevien merkitysten tulkitseminen, vaan yhdessä itse asian äärellä oleminen.

Väitöskirjassani menin vielä askeleen pidemmälle tuosta hermeneuttisen keskustelun kuvauksesta ja esitin, että ideaalia tiedon luomisen tapahtumaa voidaan ajatella leikkinä. Tähän päädyin, sillä käydessäni läpi tiedon luomista ja innovatiivisuutta peräänkuuluttavaa tutkimusta törmäsin moniin määritelmiin: tietoa luova vuorovaikutus on avointa ja luottamuksellista, keskusteluun heittäytyvää, uusiin ajatuksiin tarttuvaa. Nämä määritelmät toivat mieleeni Gadamerilta löytyvän leikin käsitteen, jonka avulla hän tarkastelee sellaista ideaalia olemisen tilaa, jossa ihminen antautuu kohtaamansa asian kanssa avoimeen keskusteluun, kuten lapset leikkiessään antautuvat tosissaan leikkiin, ainakin hetkittäin. Se on yhdessä olemista, jossa mahdollisuuksiin tartutaan ja valitaan toisin. Tällainen tila on myös lähtökohtaisesti avoin ja jaettu, siinä on sääntönsä ja tavoitteensa, jotka tukevat tapahtuman kehittymistä. Olennaista on kuitenkin huomioida, että Gadamerille leikki ei ole poissaoloa tästä maailmasta, hupailua, mielikuvitusmaailmassa kokeilua, vaan päinvastoin leikin syntyminen vaatii sen vakavasti ottamista, läsnäoloa juuri tässä hetkessä. Gadamerille leikki on siis kokonaisvaltaista läsnäoloa tapahtuman kulussa, eikä se salli vetäytymistä tarkkailijan asemaan. (Gadamer, 1999., 2004) On kuitenkin huomioitava, että niin Gadamer kuin tiedon luomisen tutkijatkin kuvaavat ideaalia yhdessä olemisen tilaa, mutta todellisuudessa vuorovaikutus on kaikkea muutakin. Toisilla ei ole aikaa kuunnella, läsnäolijat keskittyvät kännyköihinsä kokouksessa, ryhmätyötä tekevät pitävät kiinni omista näkemyksistään eivätkä ole valmiita tarkastelemaan toisten ehdotuksia vakavasti, joku yrittää laskelmoida, jotta asiat etenisivät halutulla tavalla. Leikinomaisen tilan saavuttamisen mahdollisuus organisaatioympäristön paineissa onkin kysymys, joka on innostanut tutkimustani.

Hermeneuttisen fenomenologian avulla ajassa ja paikassa toimivan ihmisen kautta tarkasteltavaksi tulee kolme aikaulottuvuutta. Ensinnäkin fenomenologia kiinnittää tiedon luojan ja koko tapahtuman aiempiin kokemuksiin. Toiseksi fenomenologinen ihmiskäsitys avaa tulevan aina avoimena ja kyseenalaistettavana: 
ihmisellä on aina mahdollisuus valita ja toimia toisin. Kolmanneksi fenomenologia korostaa nykyhetkeä, jossa mennyt ja tuleva kohtaavat yksilön ja maailman jatkuvana kohtaamisena, joka ideaalitilanteessa on kuvattavissa leikkinä. Erityistä on, että fenomenologiaan perustuen ihminen käsitetään tietoisena ja siten toimintaansa vaikuttamaan kykenevänä olentona, joka samalla on osaltaan viemässä tilannetta ja samalla koko organisaatiota tiettyyn suuntaan. Näistä edellä kerrotuista elementeistä muodostin sen teoreettisen viitekehyksen, jonka avulla saatoin ryhtyä tarkastelemaan tiedon luomista ja vuorovaikutusta empiirisesti.

Fenomenologinen lähestymistapani johti minut väitöstutkimuksessani tarkastelemaan erityisesti sitä, mitä vuorovaikutustapahtumissa tapahtuu. Tutkimukseni keskimmäisessä osassa hahmottelin, minkälaisilla menetelmillä tätä vuorovaikutuksen tapahtumaa voidaan tutkia ja päädyin esittämään, että etnografinen, työyhteisön toimintaa mahdollisimman monitahoisesti tarkasteleva lähestymistapa pystyy parhaalla mahdollisella tavalla saamaan otteen siitä, miten tiedon luomisen edellytykset juuri tutkimuksen kohteena olevassa yhteisössä osallistuvat tapahtumaan. Empiirisen tutkimukseni toteutinkin etnografisesti opettajien ja kirjastonhoitajien muodostamassa yhteisössä, joka osallistui vuosina 2013 ja 2014 valtakunnalliseen Lukuinto-ohjelmaan. Tuon yhteisön tavoitteena oli kehitellä menetelmiä ja ideoita lasten ja nuorten lukemisen innon kasvattamiseksi. Sain yhden lukuvuoden ajan seurata yhteisön muodostumista ja kehitystä kohti tavoitteitaan. Olin läsnä yhteisön tapahtumissa, havainnoin, videoin ja haastattelin yhteisön jäseniä. Lopulta päädyin analysoimaan kertyneestä aineistosta paitsi tiedon luomisen edellytyksiä, myös sitä, miten vuorovaikutuksen leikillisyys ja ajatus olemisen ajallisuudesta näyttäytyi aineistossa. Osoittautui, että tuossa yhteisössä tiedon luominen tapahtui erityisesti kasvokkaisissa tapaamisissa, ja erityisesti videoaineiston analyysi osoitti, miten yhteisön yhteinen ymmärrys kehittyi samassa tapahtumassa ollen, menneiden kokemusten tukemana, mutta myös ja erityisesti siksi, että jäsenet kykenivät ainakin hetkittäin näkemään myös tulevan avoimena ja mahdollisuuksissaan.

Tässä väitöskirjassa tutkin opettajien ja kirjastonhoitajien vuorovaikutusta työyhteisössä, jolla oli hyvin erityinen tarkoitus: huoli lasten ja nuorten lukemisesta ja erityisesti lukuinnosta oli sekä koko Lukuinto-ohjelman että siihen osallistuvien opettajien ja kirjastonhoitajien toiminnan taustalla. Luodut ideat ja uudet toimintatavat heijastelivat niitä mahdollisuuksia, joita noilla yhteisön jäsenillä juuri tuossa tilanteessa oli. Lukuinnon rahoittaneella Opetus- ja kulttuuriministeriöllä oli tarve nostaa esille lukutaidon merkitystä Pisa-tulosten heikentyessä. Kirjastolla oli paitsi tarve luoda entistä parempia yhteyksiä pääasialliseen partneriinsa, kouluihin, myös tarve saada luotua toimintatapoja, joilla kouluja saataisiin palveltua entistä yhtenäisemmällä tavalla tarjoamalla samoja konsepteja koko kaupungin kouluille. Kouluilla oli tarve kehittää opetussuunnitelmaa, jossa koulun ja kirjaston yhteistyö tulisi vahvistettua. Lisäksi jokaisella yhteisön jäsenellä oli omat tarpeensa, joku halusi 
uusia näkökulmia opetukseensa ja oli alusta asti halunnut päästä ryhmään, joku oli vaan tullut nimetyksi yhteisöön organisaationsa edustajana, mutta kaikki olivat syvästi huolissaan oppilaiden lukutaitojen kehityksestä ja myös murheissaan siitä, että osa lapsista ja nuorista ei löydä lukemisen nautintoa.

Lukuinto-yhteisön mahdollisuudet vuorovaikutukseen olivat myös erityiset: yhteisön jäsenet työskentelivät kahdeksassa eri organisaatiossa, heillä oli vain harvoin aikaa tavata toisiaan ja työntekemisen rutiinit erityisesti kouluissa olivat sellaisia, että ajan löytäminen oli haastavaa. Toisaalta Lukuinnon aihe, uusien toimintatapojen kehittäminen lukuinnon synnyttämiseksi, oli suoraan yhteydessä heidän työhönsä: oppitunnit piti joka tapauksessa pitää ja kirjastolaisten käydä kouluilla tekemässä kirjavinkkauksia, joten erilaisten projektien luominen ja toteuttaminen oli luontevaa. Toisaalta oli itsestään selvää, että ideoiden toteutukseen oli tietyt, hyvin tiukat raamit, jotka tulivat paitsi koulujen arjesta, myös taloudellisista resursseista, tai niiden puutteesta. Myös arkielämän kokonaisuus asetti rajansa vuorovaikutukselle rajaamalla yhteistä aikaa: lapset oli haettava tarhasta, työpäivän jälkeen oli ehdittävä siihen ainoaan linja-autoon, joka ajoi koululta kaupunkiin, joillekin taas yhteiset, joskin satunnaiset, automatkat kotoa töihin antoivat mahdollisuuden keskustella. Väitöskirjassa tutkinkin, miten näiden olosuhteiden tukemana, niistä huolimatta tai juuri niiden avulla, Lukuinto-yhteisön jäsenet loivat uutta tietoa, joka oli tarpeellista ja tarkoituksenmukaista juuri noissa puitteissa.

Jatkotutkimuksessani tarkastelen tiedon luomista tässä väitöskirjassa kehittämäni mallin avulla edelleen yhteisössä, jossa sekä tavoitteet, tarpeet ja olosuhteet ovat melko erilaiset kuin edellä kuvaamani. Tuleva tutkimuskohteeni, BCDC Energia, on tutkimuskonsortio, jossa viiden eri alan tutkijat toimivat yhdessä luodakseen uusiutuvaan energiaan, entistä tarkempiin sääennusteisiin ja energiankulutuksen ja -markkinoiden joustoon perustuvan pilvipalvelun.(Huotari, Suorsa, Ikonen, \& Innanen, 2016.) Näin ollen se, mikä näyttäytyy uutena tietona tutkijoille, on jotakin aivan muuta kuin opetus- ja kirjastotyössä. BCDC-yhteisön tavoitteena on luoda uutta tutkimustietoa omilla aloillaan tieteen kehittymiseksi, mutta myös tietoa suomalaisille päättäjille ja energiasta kiinnostuneille kansalaisille. Tutkijayhteisöllä on erityiset olosuhteet vuorovaikutukseen: yhteisiä tapaamisia, verkossa toimivia tiedon jakamisen ja keskustelun alustoja, joillakin päivittäisiä kohtaamisia, toisilla vain harvoin, sillä yhteisön jäsenet työskentelevät eri puolilla Oulun yliopistoa, toiset taas Helsingissä. Tavoitteetkin ovat moninaiset, tutkijoilla on tarve julkaista hyvää tutkimusta, saada jatkorahoitusta, kehittää omaa tutkimustaan henkilökohtaisesti kiinnostavaan suuntaan. Toisaalta rahoittajan toiveet, Suomen yleinen tiedepolitiikka, yliopistojen käytännöt ja tutkimusyhteisöjen erilaiset tavat rajoittavat ja mahdollistavat uuden tiedon luomista ja vuorovaikutusta. Ja edelleen ovat ne tarhassa olevat lapset, yksin kotona selviytymään pyrkivät koululaiset, läheiset ja koko elämä, joka antaa raamit sille ajalle, joka on käytettävissä työhön. 
Onkin kiinnostavaa päästä vertailemaan, miten eri tavoin työyhteisöt organisoituvat ja toimivat uutta tietoa luodakseen. Tänään tarkastettavassa väitöskirjassani esitän fenomenologisen lähestymistavan, joka korostaa jokaisen tilanteen, yhteisön ja niiden jäsenten erityisyyttä ja sitä, että myös tutkimuksen tekijän on oltava avoin tälle erityisyydelle. Samalla esitän, että ymmärtämällä ihmisen olemisen luonne fenomenologisella tavalla, kuten lektion alkupuolella esitin, voidaan ymmärtää tiedon luomisen perustaa ja hahmottaa tapoja tutkia ja kehittää tietoa luovaa vuorovaikutusta ilmiön syvällisyys huomioiden. Tietoa luova vuorovaikutus vaatii aikaa ja sellaisia olosuhteita, joissa ihmisen on hyvä heittäytyä leikkiin. Tutkimukseni ytimessä on siis fenomenologinen ajatus siitä, että jokaisessa ihmistenvälisessä kohtaamisessa on mahdollisuus muutokseen, sillä tosiaankin tuleva ei ole ennakkoon määritelty vaan avoin. Tämä yksinkertaiselta, ehkä itsestään selvältäkin kuulostava käsitys avaa toisenlaisen tavan katsoa maailmaa, sekä arkielämässä että tutkimuksessa.

\section{Lähteet}

Belkin, N. J. (1990). The cognitive viewpoint in information science. Journal of Information Science, 16(1), 11-15. https://doi.org/10.1177/016555159001600104

Budd, J. M. (1995). An Epistemological Foundation for Library and Information Science. The Library Quarterly, 65(3), 295-318. https://doi.org/10.1086/602799

Choo, C. W. (1998). The knowing organization: how organizations use information to construct meaning, create knowledge, and make decisions (s. 298). New York: Oxford University Press.

Drucker, P. F. (1982). The age of discontinuity : guidelines to our changing society (s. 369). London: Heinemann.

Drucker, P. F. (1993). Post-capitalist society (1. p., s. 232). New York: Harper Collins.

Gadamer, H.-G. (1999). Die Aktualität des Schönen. Kunst als Spiel, Symbol und Fest. Teoksessa Gesammelte Werke 8: Ästhetik und Poetik 1: Kunst als Aussage (ss. 34-143). Tübingen: J C B Mohr.

Gadamer, H.-G. (2004). Truth and method. London /New York: Continuum.

Heidegger, M. (1985). Being and time. Oxford: Blackwell.

Heinämaa, S. (1996). Ele, tyyli ja sukupuoli. Helsinki: Gaudeamus.

Huotari, M.-L., Suorsa, A., Ikonen, K., \& Innanen, K. (2016). Knowledge creation in an R\&D project. A multiple case study in the context of clean energy markets in Finland. Teoksessa Proceedings of ISIC: the information behaviour conference, Zadar, Croatia, 20-23 September, 2016: Part 1. http: //www.informationr.net/ir/21-4/isic/isics1602.html

Ingwersen, P. (1982). Search procedures in the library - analyzed from the cognitive point of view. Journal of Documentation, 38(3), 165-191. https://doi .org/10.1108/eb026727

Morner, M., \& Krogh, G. von. (2009). A Note on Knowledge Creation in Open-Source Software Projects: What Can We Learn from Luhmann's Theory of Social Systems? Systemic Practice and Action Research, 22(6), 431-443. https://doi.org/10.1007/s11213-009-9139-7

Nonaka, I., Krogh, G. von, \& Voelpel, S. (2006). Organizational Knowledge Creation Theory: Evolutionary Paths and Future Advances. Organization Studies, 27(8), 1179-1208. https://doi.org/ 10.1177/0170840606066312

Tsoukas, H. (2009). A Dialogical Approach to the Creation of New Knowledge in Organizations. Organization Science, 2o(6), 941-957. https://doi.org/10.1287/orsc.1090.0435 